\title{
Security Regulations in Mexican Renewable Energies: Case of Geothermal Projects
}

\author{
Alfonso Aragón-Aguilar, Georgina Izquierdo-Montalvo, Víctor Arellano-Gómez \\ Gerencia de Geotermia, Instituto de Investigaciones Eléctricas, Cuernavaca, México. \\ Email: aaragon@iie.org.mx \\ Received February 20 ${ }^{\text {th }}, 2013$; revised March $20^{\text {th }}, 2013$; accepted March $27^{\text {th }}, 2013$ \\ Copyright (C 2013 Alfonso Aragón-Aguilar et al. This is an open access article distributed under the Creative Commons Attribution \\ License, which permits unrestricted use, distribution, and reproduction in any medium, provided the original work is properly cited.
}

\begin{abstract}
A review of natural resources existing in México is done. The description of the renewable energies for electricity generation operating at date along the country, includes hydro, wind, solar, biomass and geothermal, among others. The installed capacity (to 2012) in México for electric generation from renewable energies is equivalent to $22 \%$ of total generation capacity. México has geothermal resources, which can be classified as high and low enthalpy, and of hot dry rock. To date, the exploitation has focused mainly on high enthalpy geothermal fields. Geothermal power plants do not burn fuel, preventing gas emissions helping to reduce global warming and greenhouse effect. Security risks in México geothermal fields, as a part of renewable energies linked to Smart Grids, are described emphasizing their geographical locations to facilitate the exposure to dangerous events. The results about research on Mexican Official Norms protecting environment related with geothermal operation projects are shown. The Mexican geothermal projects have developed under rules that provide security to workers and people, avoiding impacts on the environment. However, it was found that it necessarily emphasized previsions to damages and remedial actions for grids due to risks by natural contingencies (cyclones, winds, earthquakes) and by artificial causes such as vandalism (grids breaking, fire, explosions, etc.). Unfortunately, there are no preventive norms against natural risks. After all the analyses carried out, security must be considered by nature a dynamic and ever-changing process.
\end{abstract}

Keywords: Security; Renewable Energy; Geothermal; Hydro; Wind; Solar; Environment; Official Mexican Norms; Geothermal Fields

\section{Introduction}

Smart grid is a form of efficient management of the electricity which uses computer technology to optimize production and distribution of electricity in order to better balance supply and demand between producers and consumers. It is a concept of what the electrical power grid should look like, where the grid itself uses modern networking technology to allow different parts of the grid to communicate. The emergence of renewable energies in the energy landscape has changed significantly. The energy flows now may be bidirectional. A smart grid sends electricity from suppliers to consumers using two-way digital technology to control consumer needs. This helps to save energy, reduce costs and increase the usability and transparency. Using energy efficiently, it contributes to reduce $\mathrm{CO}_{2}$ emissions and global warming.

The new smart grids counters in homes or offices report the use of energy to electric company and indicate both to user and to power company the appropriate time to reduce the consumption of electricity from the network.

The smart grids not only provide energy but also information, including the next step in the electricity supply, applying information technology to make viable and controllable network itself, both conventional and new network elements [1]. The results of smart grids are linked with satisfying the ordinary demand and with small systems of generation and storage. The best control given by smart grids is the high flow velocity, bidirectional communications, high sensibility sensors and coordination in real time of all components of network.

The main characteristics of smart grids, among others are: allowing the active participation of consumers, optimal combination of all generation and storage options, allowing the development of new products, services and markets in the electric sector, optimizing the operation of network elements, anticipation and response to system disturbances, resistant to attacks and natural disasters. 
Smart grids can help reduce climate change by providing information in innovative ways to asses and react to the environmental impact of each user. Users can see instantly the increase and reduction carbon emissions during on or off or any changes in their appliances homes or office equipments.

The renewable energies help smart grids, in the solution of challenges in diminution of $\mathrm{CO}_{2}$ emission during electricity generation processes. The technology of smart grids is being introduced quickly in the market, according to the characteristics of each country. It is worth mentioning that incidents involving electrical systems in Europe and North America in seasons where the weather is adverse are events that also have prompted the introduction of smart grids technology. Another of the biggest challenges of deploying millions of new devices for a Smart Grid is that each of those devices could become a potential target for hackers.

The control systems of smart grids are useful tools for their effective operation. The algorithms, devices, analyze, diagnose, and predict conditions determine the appropriate corrective actions for eliminating, preventing and mitigating the disturbances in networking.

Renewable energies are compared to fossil fuels, an inexhaustible source of energy that contributes to the country's energy as self-sufficient. They are less prejudicial to environment avoiding the effects of direct uses (environment pollution, waste) and derivatives from energy generation (drilling, roads, excavations etc.). These are a profitable source for obtaining electrical energy mainly in remote localities away from network and with lack of infrastructure for interconnection. However, in developed countries with extensive electrical infrastructure, the environmental costs of each energy source compared to fossil fuels are taken into account.

Global consumption of electricity from renewable sources grew by an average of $3 \%$ from 2008 to 2009 [2]. The participation of renewable energies in total consumption of electrical energy is equivalent to an average of $20 \%$ [3]. The regions of the world leading the electricity consumption from renewable energies are Asia, North America and Europe. Table 1 shows electricity consumption by regions from renewable energies [3].

In the world, it is expected an increase in electricity generation from renewable energies for reducing gas emissions which result in greenhouse effect [4]. By increasing energy efficiency and the use of renewable energies, smart grids reduce climate change [5]. Security is primarily about people, processes and technologies working together to prevent an attack. It is not just technology, or a set of procedures, and it is not a one-time investment. There is no single solution that is effective for all organizations or applications, but effective solutions that can be developed through the cooperation of
Table 1. Electricity consumption around the world (20082009) by region, from renewable energies [3].

\begin{tabular}{ccc}
\hline Region & $\begin{array}{c}\text { Consumption (TWH) } \\
\text { 2008-2009 }\end{array}$ & $\begin{array}{c}\text { Growth (\%) } \\
\text { 2008-2009 }\end{array}$ \\
\hline Asia Pacific & 1021 & 4 \\
North America & 837 & 2 \\
Europe & 834 & 4 \\
Central and South America & 721 & 3 \\
Rest of World & 348 & 7 \\
TOTAL & 3761 & \\
\hline
\end{tabular}

vendors, systems integrators and end users.

A smart grid can alert system operators of potential problems before it causes a failure avoiding users to make calls reporting the failure [6] allowing a better analysis about interruption causes. Its recovery capacity is important as deterrent to an attack affecting the network. Security is about managing risk, but the task of defining security threats to power utility systems is a difficult one, in part because there is relatively little statistical data on security breaches. These are (thankfully) rare as compared, for example, to natural disasters like hurricanes, ice storms and the like. Nature is also fundamentally random, and as such lends itself to statistical analysis. Cyber threats, on the other hand, are posed by human beings who are able to learn and change their methods over time. Security in this context is by nature a dynamic and ever-changing process. It can be considered that it is never "completed" [7].

Security threats also do not know technical limits (i.e., there are many potential vectors of attack that might be used to circumvent security measures). This is why security experts often refer to the need to have "defense in depth," a combination of policies, procedures and technologies that are mutually reinforcing. Another distinction that should be made with regard to security in utility systems is the relationship between security and reliability. These two objectives are not always aligned, due to priorities behind each of them. Reliability and security are on the same team. If a security breach allows an intruder to disrupt the utility's operations and cause a blackout, then clearly reliability has also been disturbed.

Meeting utility security requirements in the current environment is a multi-faceted and ever-changing challenge. Security issues must constantly be revised throughout the development process with a heavy emphasis placed on security assessments and testing. The security focus is on operating the network to maximize reliability. Likewise, security professionals typically are not operational people, and their focus is on preserving the integrity and functionality of the system. Security begins with policies that address human behavior, which is the basis 
for all security whether technical, procedural or organizational. Relatively few security cases can be attributed solely to a technological failure. Some examples of basic but vital practices include: using and listening to alarms; removing unused software from servers and work stations; disabling unused services; removing unused accounts; changing default passwords regularly; verifying system setup on a redundant or test system not the production server; using host-based firewalls; regularly updating antivirus software and using a vendor's patch management process.

\section{A Review on Smart Grids in México}

The Comisión Federal de Electricidad (CFE) is the responsible sector of the Mexican government for electricity generation. It uses different sources to achieve its objective such as wind, hydro, geothermal, solar, biomass among others. The natural sources of México are important in its technological development; is part of the "sun belt" receiving an average solar radiation of 5 $\left(\mathrm{kWh} / \mathrm{m}^{2}\right)$ per day. The country has the fourth place in the world on installed capacity of electric generation from geothermal. In different states (BC, BCS, Chihuahua, Tamaulipas, Zacatecas, Oaxaca, Veracruz, Tabasco, Yucatán, among others) there are conditions for operation wind power plants [8].

The installed capacity (up 2012) in México, for electric generation from renewable energies is equivalent to $22 \%$ of total generation capacity in the country. Table 2 shows the generation capacity from each type of renewable energy. México encourages the energy sector through projects, programs and actions to achieve greater use and development of renewable energy sources and clean technologies. In the country there are more than 200 power plants from renewable energy sources. The map of Figure $1[9,10]$ shows a distribution of power plants using renewable energy along Mexican territory. Oaxaca is the Mexican state with major quantity of wind projects and Veracruz with biomass.

Due to extensive quantity and capacity of renewable sources in México it expected that total electric generation to date of 14,357 MWe would be twice for 2025 [2,9].

As it can be seen from Table 2, hydropower represents about $80 \%$ of installed capacity in México from renewable energies. Different studies [2,9,10] forecast the growth of installed capacity using renewable sources. Table 3 shows the potential which, could be developed from each energy type.

\section{An Overview on Geothermal in México}

The goal of this paper is focused to describe security
Table 2. Installed capacity of electricity generation in México (up 2012) from renewable energies [2].

\begin{tabular}{ccc}
\hline Energy type & $\begin{array}{c}\text { Installed capacity } \\
\text { operating (MWe) }\end{array}$ & $\begin{array}{c}\text { Percentage } \\
\text { participation (\%) }\end{array}$ \\
\hline Wind & 1215 & 8.46 \\
Geothermal & 958 & 6.67 \\
Hydropower & 11,603 & 80.82 \\
Solar $^{*}$ & 33 & 0.23 \\
Biomass & 548 & 3.82 \\
TOTAL & 14,357 & 100 \\
\hline
\end{tabular}

*Photovoltaic projects of small and medium scale applications mainly in residential and rural electrification.

Table 3. Potential capacity of electricity generation in México from renewable energies [2].

\begin{tabular}{cc}
\hline Energy type & Potential capacity (MW) \\
\hline Wind & 71,000 \\
Geothermal & 40,000 \\
Hydropower & 53,000 \\
Solar & 24,300 \\
Biomass & 83,500 \\
\hline
\end{tabular}

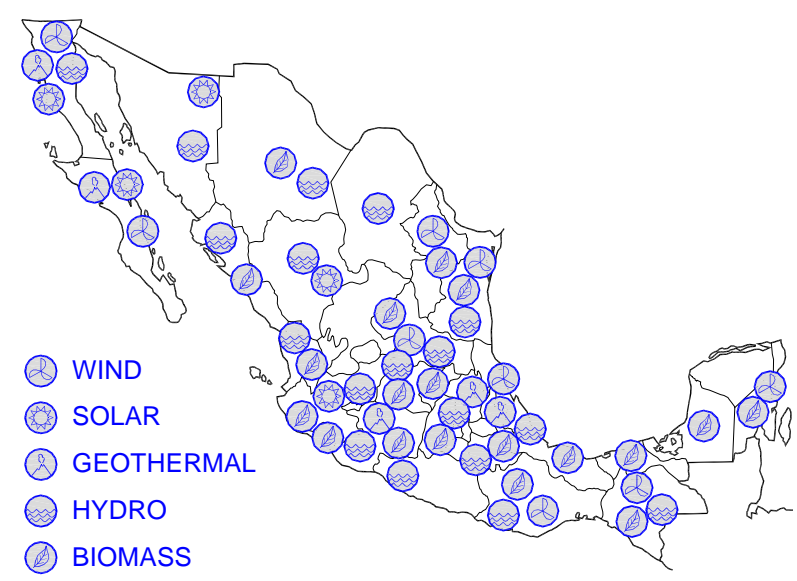

Figure 1. Mexican states with installed capacity for electricity generation from renewable sources $[9,10]$.

risks in Mexican geothermal fields, as part of renewable energies that are linked to Smart grids. Geothermal power plants do not burn fuel, preventing gas emissions and help to reduce global warming and greenhouse effect. México has geothermal resources, which can be classified as high and low enthalpy, and of hot dry rock. These last energy type mentioned would be exploited by methodology of Enhanced Geothermal System [11]. Figure 2 shows a map of thermal manifestations and the locations of geothermal fields with their respective capacity of electric generation $[10,12,13]$. 
The total capacity of electricity generation from geothermal resources is of 958 MWe through the four fields operating to date [13]. Cerro Prieto geothermal field in Mexican state of Baja California is the largest capacity in Country, to date with 720 MWe. Its first generation power plant started in operation since 1973. The total number of drilled wells in these fields is 546. Aditionally were drilled about 20 wells in other fields (La Primavera Jalisco, Las Derumbadas Puebla, and Ceboruco Nayarit). Table $4[13,14]$ shows an update summary of main characteristic parameters of each geothermal field in operation; as it can be seen the average depth, except Los Azufres, is higher than $2000 \mathrm{~m}$.

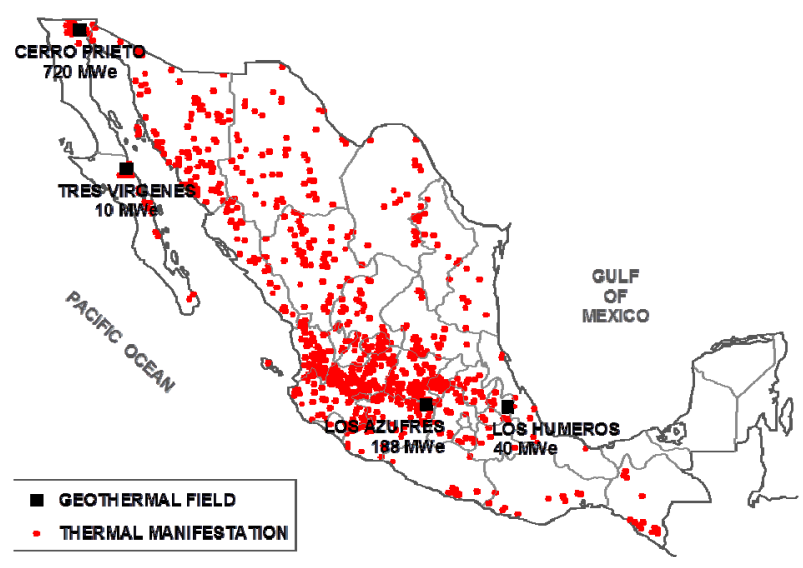

Figure 2. Locations of thermal manifestations in Mexican territory sampled by CFE, operating fields and geothermal power plants $[10,12,13]$.

Table 4. Updated summary of characteristic parameters of the four Mexican geothermal fields in operation [13,14].

\begin{tabular}{|c|c|c|c|c|}
\hline Data/Field & $\begin{array}{c}\text { Cerro } \\
\text { Prieto BC }\end{array}$ & $\begin{array}{l}\text { Los Azufres } \\
\text { Mich. }\end{array}$ & $\begin{array}{c}\text { Los } \\
\text { Humeros } \\
\text { Pue. }\end{array}$ & $\begin{array}{c}\text { Las tres } \\
\text { Vírgenes } \\
\text { BCS }\end{array}$ \\
\hline $\begin{array}{l}\text { Installed Capacity } \\
\text { (MWe) }\end{array}$ & 720 & 188 & 40 & 10 \\
\hline $\begin{array}{l}\text { Production wells } \\
\text { (number) }\end{array}$ & 172 & 39 & 23 & 4 \\
\hline $\begin{array}{l}\text { Injection wells } \\
\text { (number) }\end{array}$ & 16 & 6 & 3 & 1 \\
\hline $\begin{array}{l}\text { Brine flow rate } \\
\text { production(t/h) }\end{array}$ & 7325 & 568 & 65 & 230 \\
\hline $\begin{array}{l}\text { Average flow rate of } \\
\text { Brine by well }(\mathrm{t} / \mathrm{h})\end{array}$ & 42.6 & 14.6 & 2.8 & 57.5 \\
\hline $\begin{array}{l}\text { Steam flow rate } \\
\text { production }(\mathrm{t} / \mathrm{h})\end{array}$ & 4562 & 1668 & 581 & 71 \\
\hline $\begin{array}{l}\text { Average flow rate of } \\
\text { steam by well }(\mathrm{t} / \mathrm{h})\end{array}$ & 26.5 & 42.8 & 25.3 & 17.8 \\
\hline $\begin{array}{l}\text { Total number of } \\
\text { drilled wells }\end{array}$ & 402 & 88 & 45 & 11 \\
\hline $\begin{array}{l}\text { Average depth } \\
\text { by well (m) }\end{array}$ & 2392 & 1583 & 2179 & 2037 \\
\hline $\begin{array}{l}\text { Average bottomhole } \\
\text { temperature }\left({ }^{\circ} \mathrm{C}\right)\end{array}$ & 310 & 340 & 360 & 280 \\
\hline
\end{tabular}

Before pointing out the security concepts of the four geothermal fields in operation within Smart Grids, it is appropriate describe the environment where they are located. General data on location of these geothermal fields are as follows:

1) The Cerro Prieto geothermal field is located about $40 \mathrm{~km}$ to southeast of Mexicali city, between meridians $115^{\circ} 12^{\prime}$ and $115^{\circ} 18^{\prime}$ west long and parallels $32^{\circ} 22^{\prime}$ and $32^{\circ} 26^{\prime}$ north latitude [15].

2) The Los Azufres geothermal field is located $80 \mathrm{~km}$ to east of Morelia City into the San Andrés mountain, between meridians $100^{\circ} 38^{\prime} 32^{\prime \prime}$ and $100^{\circ} 43$ '38" west long and parallels $19^{\circ} 45^{\prime} 12^{\prime \prime}$ and $19^{\circ} 500^{\prime} 08^{\prime \prime}$ north latitude [16].

3) The Los Humeros geothermal field is located at the border of Puebla and Veracruz states, about $30 \mathrm{~km}$ to north of Perote town, located between $97^{\circ} 23^{\prime}$ and $97^{\circ} 35^{\prime}$ west long and $19^{\circ} 35^{\prime}$ and $19^{\circ} 45^{\prime}$ north latitude [17].

4) The geothermal field of Las Tres Vírgenes is located at the eastern end of the peninsula of south Baja California between $112^{\circ} 24^{\prime}$ and $112^{\circ} 40^{\prime}$ west long and $27^{\circ} 40^{\prime}$ and $27^{\circ} 59^{\prime}$ north latitude [18].

General visualization on the wells location on the four geothermal fields is shown in Figures 3 to 6 .

From the images taken from Google Earth it can be distinguished the major or minor density of trees in each field. We introduced some marks as reference characteristics, such as the location of power plants, or representative wells in each field. So it is feasible to assume that the Los Azufres geothermal field is located in a woodland zone. However the Cerro Prieto geothermal field is in a desert zone [14]. The Los Humeros geothermal field is classified as an area little wooded and Las Tres Vírgenes field as a semidesert area [19,20].

The above description about the environment of Mexican geothermal fields is useful to understand security concepts related to geothermal as a renewable source and

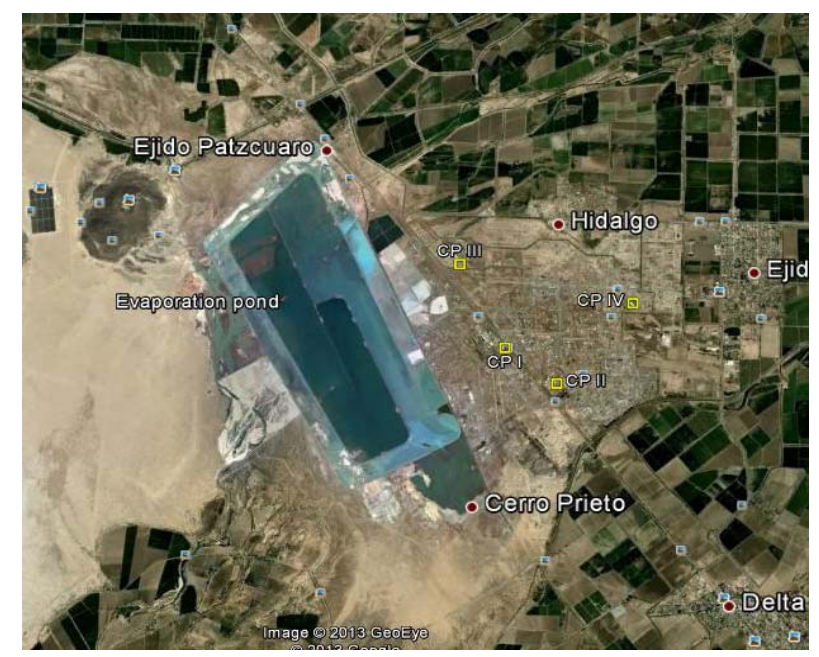

Figure 3. General environment view, power plants and particular characteristics of the Cerro Prieto geothermal field. 


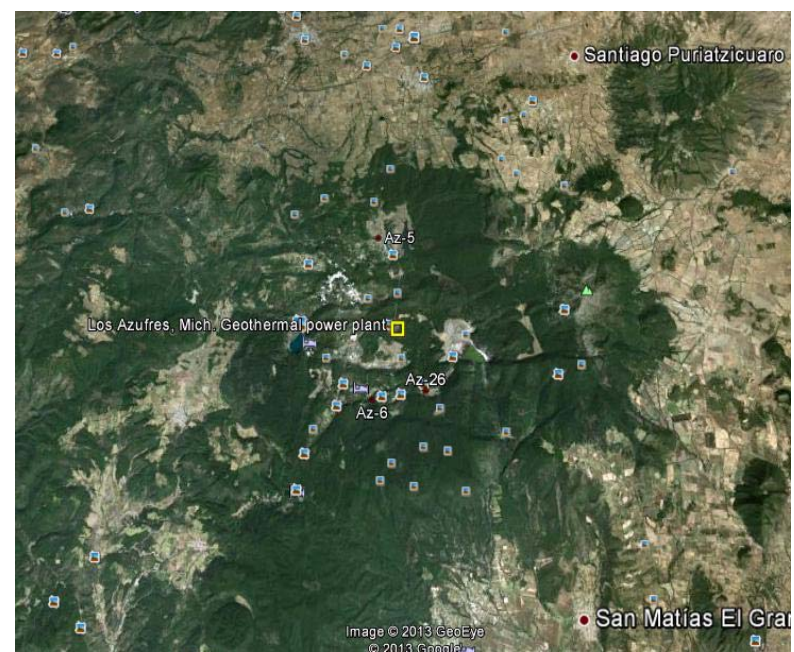

Figure 4. Image showing location of wells limiting the exploitation area, characteristic lakes, power plant and general environment of Los Azufres geothermal field.

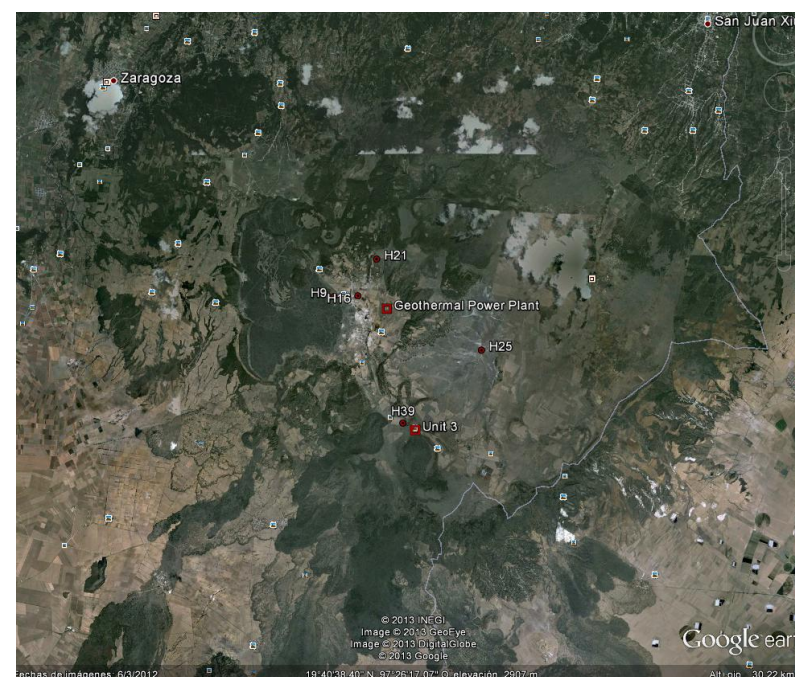

Figure 5. Image indicating representative places, main geological structures and environment of Los Humeros geothermal field.

its relation to smart grids. The security in a geothermal project covers to environment, to people to utilities and distribution grids.

\section{Security in Operations of a Geothermal Project}

A geothermal project involves stages of exploration, drilling, well testing, production evaluation, operation (power plant and wells) and wells repairing. Taking into account these activities the security risks are described following.

\subsection{Exploration Stage}

This stage involves geological-geophysical research and

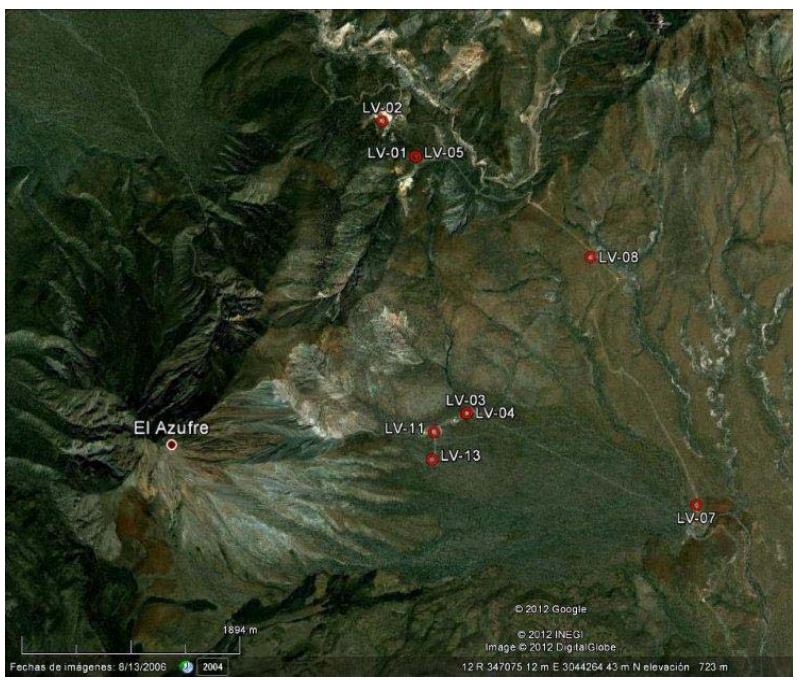

Figure 6. Image showing wells and geothermal field environment of Las Tres Vírgenes.

sampling of fumaroles and thermal manifestations for geochemical studies. The security risks during exploration are mainly related with personal accidents and with vandalism against technical staff.

By this reason is highly recommended that exploration team be composed by at least five technical people. The risks for technicians participating in this stage are the natural topography of the work, the climatic conditions, the rain, the cold weather etc. among others. The transport and handling of geophysical research equipment is another cause of security risk by the vandalism against equipment. According with [21-24] the sampling techniques include the use of appropriate equipment, clothing and accessories for obtaining representative brines and gases, taking into account protection of sampling personnel.

\subsection{Drilling Stage}

The security risks in this project stage mainly are accidents by the use of heavy equipment, chemical additives of drilling fluids, gases emission and temperature during chemical sampling of drilling fluids. Other incidents influencing in security of the project and for personnel working are fuels combustion of machinery, difficult access from and to towns by rural roads in case of any inconvenience such as the wells blowout.

The environment impacts during drilling stage are due to construction of roads for accessing to wells localities, ground compaction and excavations for drilling mud ponds. The noises of machinery of drilling equipment composed by winch, compressors and pumps of drilling fluid circulation are elements impacting the environment and personnel working. The combustion gases emission, residuals of lubricants, greases and drilling fluid also are 
factors of security risks to environment and workers. Different Mexican standards for environmental protection are applied by CFE during development of geothermal projects. So [25] establishes the maximum noise levels, [26] regulates the gases emission by fuels combustion, [27] is applied for waste water. The regulation for handling residuals of greases and lubricants from drilling jobs is established in $[28,29]$. The prevention of aquifer contamination is regulated through [30]. The norm developed according to characteristics of Mexican geothermal fields [23] is focused to environment and people protection, covering aspects to be applied in this stage of geothermal project.

\subsection{Well Tests}

Temperature and pressure logs, transient pressure tests through water injection at different flow rates, sampling cuts in drilling mud are the different actions at well completion stage. The analysis results are useful for making decisions to define the best production thickness for well completion. The security risks in this stage are locations of wells away from towns, the lack of clear and appropriate communications, fatigue due to long workdays for tests, rain, cold weather, etc. It is highly recommended to create working groups that can alternate in the technical responsibilities of these operations. The security for operative personnel is based in official Mexican norm [24] which covers working aspects.

\subsection{Productions Evaluations}

Reservoir engineers, production, geochemical, mechanical among others, are different specialists involved in well productivity characterization. Their preparation and experience is aimed to solving technical and practical challenges in this type of field operations. Adversity climate, terrain, gas emission from wells, the problems in communication, and even vandalism are the security risks for the working group. During injection tests, pump motors generate noise and gases impacting health of technical personnel and environment, by this reason CFE applies security procedures established in regulation [25]. High temperatures of produced fluid are a security risk for people and environment (vegetation, atmosphere, animals). Pressure in discharge pipes are a security risk for people. The security regulations [22,23] allow protect of damage against risks from operations under these conditions. These norms regulate the discharges of production evaluations of wells.

The measurements of noise in geothermal fields are carried out by CFE in order to implement actions for accomplish the maximum limits from fixed sources established in [31]. The results of wells production evaluation are applied for establishing production designs, equipment installation (valves, separators, silencers, pipes, etc) for wells operation, and fluid transport to power plant. The accuracy of the evaluation results is the basis for field expansion projects. The interconnection designs of the power plant with general distribution system are projected in this stage therefore the evaluations are a main activity in smart grid operation.

\subsection{Continuous Operation}

During the stage of well exploitation and after its incurporation to the network of steam transporting to the power plant, the security risks to environment occur in the well locations, as in the power plant. The causes of the environmental impact are brines with precipitates, water vapors, gases and noises. Fluid sampling is risky, to people security, because some of the chemical species in the liquid and gas phase. The measurement instruments, security equipment and working clothes must be resistant to high temperatures and corrosive fluids [24].

The security to people and installations is guaranteed by Mexican Army at the power plants, however off-site (producer wells and network pipes) there is not security and could exist vandalism acts. Figures $\mathbf{3}$ to $\mathbf{6}$ show locations of Mexican geothermal fields and can be seen that are away from towns, it diminishes impact risk to people, but could be risks to local environment (flora and wildlife). During continuous exploitation, the production parameters of wells are evaluated periodically in order to characterize their trends which normally are related to the decline.

The continuous monitoring includes measurements of pressure and temperatures at the wellhead, at separator, at steam pipes (instruments of differential pressure) at measurement instruments of channels of discharged brine, among others. A natural response to exploitation is the variations of productive characteristics (mass flow, pressure, enthalpy, etc., among others) influencing in performance reduction of the well. These factors indicate reservoir decline and the wells which have entered in this process are replaced by new drilling in order to meet with steam requirements of power plant. However in the majority of cases the production starts to decline after a time operation. This duration is function of reservoir characteristics (Permeability, porosity, flow, chemical composition, recharge etc.). For preventing an unexpected decline it is important continuously monitoring all reservoir characteristics for taking decisions about changes to apply in the well exploitation.

The residual water discharges, combustion gases emissions and noises produced by equipment operations are regulated [25-27,32]. The CFE provides security equipment and working clothes to avoid impact risks to environment and people. For monitoring chemical and iso- 
topic behavior of wells and reservoirs, fluids are sampled in specific points: a) Along pipes transporting steam to power plants; b) At the discharge channels, c) At the storage ponds for brine cooling before reinjection. High temperatures in sampling places are the security risks for personnel working in these activities, so it is mandatory to use tools, working and protection equipment resistant to critical temperatures operation [23].

\subsection{Maintaining and Wells Repair}

The equipment, machinery, pumps, compressors, etc., used in this stage are similar to those used during drilling. The only one difference is that a repair is done in less time than the drilling. The impact risks to environment are due to combustion gases and noises of motors, besides residual disposal of fluids and materials. The official Mexican norms [25,26,28,33] establish limits for combustion gases emission and noise from motors, pumps, compressors etc., and respective residual disposal. The aquifers protection during maintain and repair of wells is regulated [34]. The security risks for personnel working health are: exposition to inclement weather, handling heavy equipment, high level of noise even though, the CFE provides protection equipment to avoid these impact risks.

\subsection{Laboratories Work}

The drilling cuts are analyzed at laboratories, also the fluid sampled during evaluation discharges, production tests and continuous operation. The main security risk to working personnel of geothermal laboratories is by handling of chemical substances and acids being used as reactive material [24]. The security risk to environment is the use of laboratory equipment, material and chemical substances in the analyses [28].

\section{Comments and Discussion}

The article 81 of law of National Waters [35] establishes that exploitation, use and exploitation of groundwater in steam phase or with temperature higher to $80^{\circ} \mathrm{C}$, with possibility of aquifer affectation requires prior permission for geothermal generation or other applications, in order to evaluate environment impact. The CFE applies damage repair processes, which include handling of sanitary residuals, control in construction activities and in personnel working, restoring of original conditions, reforestation activities in area, among others [36]. Before the advent of official Mexican norm [23], the regulations about gases emission, noise, material residuals, waste water, soils contamination, etc., were done through norms adapted from sanitary and environmental engineering.
The development of an environmental standard appropriate to the characteristics of Mexican geothermal fields is the result of technological consolidation of this industry. Power generation from geothermal energy in México as a renewable source, operates with security to environment and people, obeying established standards. It is important to emphasize that official Mexican norms are in agreement with international standards.

Following are shown the different norms being applied in geothermal Mexican projects. These are ordered by institution and their sequential number, although the date does not appear with ordered manner. The year corresponds to date they were published at the Official Federation Daily (DOF).

\subsection{National Water Commission (CNA)}

NOM-003-CNA-1996 [30]: Requirements to take into account during drilling wells for water extraction in order to prevent aquifers contamination. This standard is adapted from water drilling wells to apply during drilling of geothermal wells.

NOM-004-CNA-1996 [34]: Requirements for aquifers protection during maintenance and repair of wells and for their general closure. This standard also is adapted from water wells for be applied during operation, repair and maintain of geothermal wells.

\subsection{Secretary of Environment and Natural Resources (SEMARNAT)}

NOM-001-SEMARNAT-1996 [27]: Establishes the maximum limits of contaminants that may contain discharges of wastewater in waters and national terrains. With exception in the exploration stage, in all the stages of a geothermal Project there are discharges of wastewater, therefore this norm is applied in those stages.

NOM-041-SEMARNAT-2006 [29]: This standard establishes the maximum permissible limits gases emission from auto motors vehicles using gasoline as fuel. During drilling and repair operations there are gas emanations from the equipment motors. Along discharge evaluations and power plant operation, the vehicles transporting personnel discharge some gases even in less quantity however this norm is applied in these stages.

NOM-045-SEMARNAT-2006 [26]: It establishes the maximum permissible levels of smoke opacity discharged by vehicles auto motors in circulation, which use diesel or mixtures with diesel as fuel. This norm is applied during drilling and wells repair, because the continuous vehicles traffic carrying equipment, tools, materials and personnel working during these stages. Besides along discharge evaluations and power plant operation, the vehicles transporting personnel discharge some gases even in less quantity; however this norm also is applied 
in these stages.

NOM-052-SEMARNAT-2005 [33]: Establishes characteristics of dangerous wastes, list of them and limits for considering a residual as danger by its toxicity to environment. The standard is applied during drilling, well tests, production evaluation, continuous operation, repair, and laboratory analysis, because in all of these stages are produced waste materials.

NOM-054-SEMARNAT-1993 [21]: Establishes the procedure for determining the incompatible between different wastes considered as dangerous by [33]. It is applied in all the stages, because in all of these are produced waste materials and need to be characterized.

NOM-059-SEMARNAT-2010 [22]: Environmental protection-Mexican native species of flora and faunarisks categories and specifications to include, exclude or change-list of species in risk. This standard is focused to general environmental protection covering native flora, fauna and species in dangerous risk, therefore is applied in all the stages of a geothermal project.

NOM-080-SEMARNAT-1994 [25]: Establishes the maximum limits acceptable of noise emissions produced by vehicles or other motorized circulating in the working area and the measurement method. The vehicles circulate in the working area mainly during drilling, repair and continuous operation delivering steam flow to power plant. Therefore this standard is applied in these stages.

NOM-081-SEMARNAT-1994 [31]: Establishes the maximum permissible limits of noise emissions from fixed sources and the method for measuring it. The only fixed sources of noise emission are the power plants because the other noise sources, such as drilling, evaluation and wells repair are temporaries. The scope of this standard is for be applied during continuous operation of a geothermal project.

NOM-114-SEMARNAT-1998 [32]: Establishes the specifications of environmental protection for planning, design, construction, operation and maintenance of electric conduction grids, for operation in urban, suburban, rural, agricultural area, industrial, services and tourism. The aspects covered by this standard are related with those corresponding to operational stage of electricity generation and distribution through networks.

NOM-138-SEMARNAT/SA1-2003 [28]: Establishes maximum acceptable limits of hydrocarbon wastes in soils and specifications for characterization and respective remediation. The guidelines of this standard are applied mainly in drilling and repair stages because the hydrocarbons and their related are used during such operations.

NOM-150-SEMARNAT-2006 [23]: Establishes technical specifications of environmental protection that must be observed in construction and preliminary assessment activities of geothermal wells for exploring, located in agricultural areas, livestock and wasteland, offsite from natural protected areas, and forest land. The regulations mentioned in this standard are applied in all the stages of Mexican geothermal projects due to its extensive coverage.

\subsection{Secretary of Work and Social Provision (STPS)}

NOM-011-STPS-2001 [24]: Establishes regulations for safety and health conditions in working places producing noise. It is applied during all the stages of a geothermal project, except exploration, because machines, discharging wells, power plant, distribution networking and laboratory equipment, are noise generation sources.

A quickly review, of the norms established for prevent impacts to security of people and environment is shown in Table 5. This table shows the issuing institution, identification of norm and the stage for applying.

Besides the above mentioned regulations, the CFE takes into account National Development Plan for the zone and their ecological programs, to start each new geothermal project. The relevant activities of a geothermal project, which can produce a risk of environmental impact, among others are [37,38]: 1) Emission to the atmosphere of non-condensable gases; 2) Constructions and infrastructure; 3) Waste generation by wells drilling, construction, maintenance and installations repair; 4) Waste water, 5) Electric generation; 6) Use of machinery and equipment producing noise and combustion gases emission; 7) Excavations and road constructions; 8) Compacting and conditioning of sites for wells and generating plants.

Perceptible impact factors in the environment of geothermal project $[37,38]$ are: 1 ) Changes in the air quality due to motors smoke, powder in the air during constructions and $\mathrm{CO}_{2}, \mathrm{H}_{2} \mathrm{~S}$ emissions among other gases by operation plants; 2) Improve in local economy by jobs generating, directly from the project and indirectly from related services such as laundry, foods, hosting etc.; 3) Increase in noise levels due to drilling operations, compaction and conditioning of well sites, access roads, power plant, and energy generation and distribution; 4) Alteration conditions for vegetable and animal species of the environment.

\section{Conclusions}

The renewable energies help smart grids, in the solution of challenges in diminution of $\mathrm{CO}_{2}$ emission during electricity generation processes, by reducing climate change and impact to environment.

The natural sources of México are important on the technological development. The installed capacity (to 2012) in México for electric generation from renewable energies is equivalent to $22 \%$ of total electric generation capacity in the country. 
Table 5. Summary of regulations related to people and environment, which are applied in different stages of Mexican geothermal projects.

\begin{tabular}{|c|c|c|}
\hline Institution & Number Regulation & Stages of applicability \\
\hline${ }^{*} \mathrm{CNA}$ & NOM-003-CNA-1996 [30] & Drilling \\
\hline${ }^{*}$ CNA & NOM-004-CNA-1996 [34] & Repair and maintenance \\
\hline${ }^{* *}$ SEMARNAT & NOM-001-SEMARNAT-1996 [27] & All the stages, except exploration \\
\hline ** SEMARNAT & NOM-041-SEMARNAT-2006 [29] & $\begin{array}{l}\text { Drilling, repair, evaluation, } \\
\text { power generation }\end{array}$ \\
\hline${ }^{* *}$ SEMARNAT & NOM-045-SEMARNAT-2006 [26] & $\begin{array}{c}\text { Drilling, repair, evaluation, } \\
\text { power generation }\end{array}$ \\
\hline ** SEMARNAT & NOM-052-SEMARNAT-2005 [33] & $\begin{array}{l}\text { Drilling, repair, evaluation, } \\
\text { power generation, laboratory tests }\end{array}$ \\
\hline${ }^{* *}$ SEMARNAT & NOM-054-SEMARNAT-1993 [21] & All the stages \\
\hline${ }^{* *}$ SEMARNAT & NOM-059-SEMARNAT-2010 [22] & All the stages \\
\hline${ }^{* *}$ SEMARNAT & NOM-080-SEMARNAT-1994 [25] & Drilling, repair, power generation \\
\hline${ }^{* *}$ SEMARNAT & NOM-081-SEMARNAT-1994 [31] & Power generation \\
\hline${ }^{* *}$ SEMARNAT & NOM-114-SEMARNAT-1998 [32] & Power generation \\
\hline${ }^{* *}$ SEMARNAT & NOM-138-SEMARNAT-2003 [28] & Drilling, repair \\
\hline${ }^{* *}$ SEMARNAT & NOM-150-SEMARNAT-2006 [23] & All the stages \\
\hline${ }^{* * *}$ STPS & NOM-011-STPS-2001 [24] & All the stages \\
\hline
\end{tabular}

*CNA.-Comisión Nacional del agua (Water National Commission); ${ }^{* *}$ SEMARNAT.-Secretaria del Medio Ambiente y Recursos Naturales (Secretary of environment and natural resources); ${ }^{* * *}$ STPS.- Secretaría del Trabajo y Previsión Social (Secretary of work and social provision).

México encourages the energy sector through projects, programs and actions to achieve greater use and development of renewable energy sources and clean technologies because it has resources for electric generation using hydro, wind, solar, biomass and geothermal.

The total capacity of electricity generation from geothermal resources is 958 MWe through the four fields operating to date. Mexican geothermal projects have developed under rules that provide security to workers and people, avoiding impacts to the environment.

A review of the different Mexican official standards related with gases combustion emissions, noise, wastewaters, soils contamination by residual hydrocarbons, brine discharges, has been carried out.

The Official standard Mexican developed considering particular characteristics of fields and geothermal projects of the country is focused on guaranteeing the security of people and environment. The regulations mentioned in this standard are applied in all the stages of Mexican geothermal projects and the coverage is extensive.

The combination of different Mexican Official standards, at present covers safety aspects, personnel health and environment protection, however, needs to be updated periodically according to technological developments.

However, it was found that it's necessary to emphasize previsions to damages for grids due to risks by natural contingencies (cyclones, winds, earthquakes) and by artificial causes such as vandalism (grids breaking, fire, explosions, etc.).

In geothermal projects, the physical security risks, mainly due to vandalism, are focused on wells installations, steam networks, energy transmission grids. The power plants security is guaranteed by Mexican Army.

It is recommended continuous monitoring of well performance for preventing its production decline to meet with requirements of steam delivering to power plant.

\section{Acknowledgements}

The authors express their gratitude to the authorities of Instituto de Investigaciones Eléctricas by the support to publish this work. The suggestions and comments of reviewers and editors of Journal Smart Grid and Renewable Energy for improving it are appreciated.

\section{REFERENCES}

[1] R. J. Lorente, "Estudio Sobre el Estado Actual de Las Smart Grids,” Proyecto de Fin de Carrera I. T. I. Electricidad, Departamento de Ingeniería Eléctrica, Universidad Carlos III de Madrid, España, 2011.

[2] Pro Mexico, “Energías Renovables,” Unidad de Inteligencia de Negocios, Inversión y Comercio, México, D. F., 2012, 39 p. 
[3] EIA, US Energy Information Administration, “Annual Energy Outlook 2013,” AEO 2013 Early Release Overview, Department of Energy, Washington DC, 2013, 16 p. http://www.eia.gov/forecasts/aeo/e/pdf/0383er(2013).pdf

[4] IEA, “World Energy Outlook, WEO 2012,” International Energy Agency, Paris, 2012, pp. 211-241. http://www.worldenergyoutlook.org/media/weowebsite/2 012/WEO2012_Renewables.pdf

[5] F. J. Barrio, "Perspectivas de las Redes Eléctricas Inteligentes en Europa,” Centro de Investigaciones Energéticas, Medioambientales y Tecnológicas (CIEMAT), Relaciones Internacionales y Cooperación, Asunción, Paraguay, 2010. http://www.olade.org/electricidad/Documents/ponencias/ Dia\%2027\%20de\%20mayo113

[6] Network World, "Las Redes Inteligentes Transformarán el Rol de Los Administradores de TI,” Computer World México, 2012.

http://www.computerworldmexico.mx/Artículos/

[7] ABB Inc., North America Corporate Headquarters, “Are We Ready for Digital Safety? Safety Applications in Conjunction with Networks Will Be the Future in the Automation World," Power and Productivity for a Better World, August 2012, 5 p.

http://www.controldesign.com/articles/2012/eberhard-arewe-ready-for-digital-safety.html

[8] Boletín Eólica, "Energías Renovables, el Periodismo de las Energías Limpias,” Secretaria de Energías, México, 2012. http://www.energias-renovables.com/articulo

[9] DOF, Diario Oficial de la Federación, "Resolución por la que la Comisión Reguladora de Energía Aprueba y Expide el Modelo de Contrato de Interconexión Para Fuente Colectiva de Energía Renovable o Sistema Colectivo de Cogeneración Eficiente en Pequeña Escala,” Comisión Reguladora de Energía, México, 2010, 10 p.

[10] N. Zapata, "La Geotermia, el Crecimiento Mas Factible en el Sector Mexicano de Energías Renovables,” New Energy Connections, August 2012, 6 p. http://www.renewableenergymexico.com

[11] J. W. Tesler, B. J. Anderson, A. S. Batchelor, D. D. Blackwell, R. DiPippo, E. M. Drake, J. Garnish, B. Livesay, M. C. More, K. Nichols, S. Petty, M. N. Toksoks and R. W. Veatch Jr., "The Future of Geothermal Energy: Impact of Enhanced Geothermal Systems on the United States in the $21^{\text {st }}$ Century," Prepared by the Massachusets Institute of Technology, under Idaho National Laboratory Subcontract No. 6300019 for the US Department of Energy, Assistant Secretary for Energy Efficiency and Renewable Energy, Office of Geothermal Technologies, 2006, 358 p.

[12] R. E. Iglesias, R. J. Torres, I. Martínez-Estrella and N. Reyes-Picaso, "Summary of the 2010 Assessment of Medium to Low Temperature of Mexican Geothermal Resources," Geothermal Resources Council Transactions, Vol. 34, 2010, pp. 1155-1159.

[13] L. C. Gutiérrez-Negrín, "Update of the Geothermal Electric Potential in México,” Geothermal Resources Council Transactions, Vol. 36, 2012, p. 677.

[14] L. G. Hiriart, N. L. Gutiérrez, L. L. Quijano, C. A. Ornelas, S. Espíndola and I. Hernández, "Evaluación de la
Energía Geotérmica en México,” Informe para el Banco Interamericano de Desarrollo y la Comisión Reguladora de Energía, México, 2011, 167 p.

[15] Gerencia de Proyectos Geotermoeléctricos de la CFE, "Manifestación del Impacto Ambiental, Modalidad Particular, Proyecto Geotermoeléctrico Cerro Prieto V," Departamento de Prevención de Impactos Ambientales, Gerencia de Proyectos Geotermoeléctricos de la Comisión Federal de Electricidad, Morelia, Mich, México, 2007, 263 p.

http://www.sinat.semarnat.gob.mx/dgiraDocs/documento s/cp

[16] Gerencia de Proyectos Geotermoeléctricos de la CFE, "Manifestación del Impacto Ambiental Modalidad Particular Proyecto Geotermoeléctrico Los Azufres III,” Departamento de Prevención de Impactos Ambientales, Gerencia de Proyectos Geotermoeléctricos de la Comisión Federal de Electricidad, Morelia, Mich, México, 2010, 556 p.

http://www.sinat.semarnat.gob.mx/dgiraDocs/documento $\mathrm{s} / \mathrm{mich}$

[17] E. Gómez-Arias, J. Andaverde, E. Santoyo and G. Urquiza, "Determinación de la Viscosidad y su Incertidumbre en Fluidos de Perforación Usados en la Construcción de Pozos Geotérmicos: Aplicación en el Campo de Los Humeros, Puebla, México,” Revista Mexicana de Ciencias Geológicas, Vol. 26, No. 2, 2009, pp. 516-529.

[18] S. S. Venegas, F. J. Arredondo, S. G. Ramírez, A. M. Flores and M. M. Ramírez, "Monitoreo Sísmico Durante la Estimulación Ácida de los Pozos LV-4 y LV-13 del Campo Geotérmico de Las Tres Vírgenes, BCS, México,” Geotermia, Revista Mexicana de Geoenergía, Vol. 19, No. 2, 2006, pp. 13-22.

[19] J. M. Romo-Jones, V. Wong-Ortega, C. Flores-Luna and R. Vázquez-González, "Conductividad Eléctrica y Atenuación de Ondas de Coda en el Campo Geotérmico Las Tres Vírgenes en Baja California Sur, México,” Geos, Vol. 20, No. 1, 2000, pp. 21-29.

[20] C. Arguelles, F. Salinas, A. Ortega-Rubio, A. Nieto, A. Naranjo, R. Aguilar, H. Romero and J. L. León, "La Protección Ambiental en la Construcción de Pozos Exploratorios del Campo Geotérmico de Las Tres Vírgenes B. C. S.," Geotermia, Revista Mexicana de Geoenergía, Vol. 10, No. 2, 1994, pp. 9-17.

[21] DOF, Diario Oficial de la Federación, “Norma Oficial Mexicana NOM-054-SEMARNAT-1993 Que Establece el Procedimiento Para Determinar la Incompatibilidad Entre Dos o Más Residuos Considerados Como Peligrosos por la Norma Oficial Mexicana NOM-052-SEMA RNAT-1993,” Publicada el 22 de Octubre, Secretaria del Medio Ambiente y Recursos Naturales, México, 1993, 37 p.

[22] DOF, Diario Oficial de la Federación, “Norma Oficial Mexicana, NOM-059-SEMARNAT-2010. Protección Ambiental-Especies nativas de México de flora y Fauna Silvestres-Categoría de Riesgo y Especificaciones Para su Inclusión, Exclusión o Cambio-Lista de Especies en Riesgo,” Publicada el 30 de diciembre, Secretaria del Medio Ambiente y Recursos Naturales, México, 2010, 78 p. 
[23] DOF, Diario Oficial de la Federación, “Norma Oficial Mexicana NOM-150-SEMARNAT-2006, Que Establece las Especificaciones Técnicas de Protección Ambiental Que Deben Observarse en las Actividades de Construcción y Evaluación Preliminar de Pozos Geotérmicos para Exploración, Ubicados en Zonas Agrícolas, Ganaderas y Eriales, Fuera de Áreas Naturales Protegidas y Terrenos Forestales,” Publicada el 6 de Marzo, Secretaria del Medio Ambiente y Recursos Naturales, México, 2007, pp. 35-44.

[24] DOF, Diario Oficial de la Federación, "Norma Oficial Mexicana NOM-011-STPS-2001, Condiciones de Seguridad e Higiene en Los Centro de Trabajo Donde se Genere Ruido,” Publicada el 17 de Abril, Secretaria del Trabajo y Previsión Social, México, 2002, pp. 101-128.

[25] DOF, Diario Oficial de la Federación, “Norma Oficial Mexicana, NOM-080-SEMARNAT-1994, Que Establece Los Límites Máximos Permisibles de Emisiones de Ruido Provenientes del Escape de los Vehículos Automotores, Motocicletas y Triciclos Motorizados en Circulación y sus Métodos de Medición,” Publicada el 13 de Enero, Secretaria del Medio Ambiente y Recursos Naturales, México, 1995, 10 p.

[26] DOF, Diario Oficial de la Federación, "Norma Oficial Mexicana, NOM-045-SEMARNAT-2006, Protección Ambiental-Vehículos en Circulación Que Usan Diesel Como Combustible.- Límites Máximos Permisibles de Opacidad, Procedimiento de Prueba y Características Técnicas del Equipo de Medición,” Publicada el 13 de Septiembre, Secretaria del Medio Ambiente y Recursos Naturales, México, 2007, 13 p.

[27] DOF, Diario Oficial de la Federación, “Norma Oficial Mexicana, NOM-001-SEMARNAT-1996 Que Establece Los Límites Máximos Permisibles de Contaminantes en las Descargas de Aguas Residuales en Aguas y Bienes Nacionales,” Publicada el 6 de Enero, Secretaria del Medio Ambiente y Recursos Naturales, México, 1997, 35 p.

[28] DOF, Diario Oficial de la Federación, "Norma Oficial Mexicana, NOM-138-SEMARNAT/SA1-2003, que Establece los Límites Máximos Permisibles de Hidrocarburos en Suelos y las Especificaciones para su Caracterización y Remediación,” Publicada el 29 de marzo, Secretaria del Medio Ambiente y Recursos Naturales, México, 2005, 21 p.

[29] DOF, Diario Oficial de la Federación, "Norma Oficial Mexicana NOM-041-SEMARNAT-2006, Que Establece los Límites Máximos Permisibles de Emisión de Gases contaminantes Provenientes del Escape de Los Vehículos Automotores en Circulación Que Usan Gasolina Como Combustible,” Publicada el 6 de Marzo, Secretaria del Medio Ambiente y Recursos Naturales, México, 2007, pp. 35-41.
[30] DOF, Diario Oficial de la Federación, “Norma Oficial Mexicana, NOM-003-CNA-1996, Requisitos Durante la Construcción de Pozos de Extracción de Agua Para Prevenir la Contaminación de Acuíferos,” Publicada el 3 de Febrero, Secretaria del Medio Ambiente, Recursos Naturales y Pesca-Comisión Nacional del Agua, México, 1997, 7 p.

[31] DOF, Diario Oficial de la Federación, “Norma Oficial Mexicana, NOM-081-ECOL-1994, Que Establece los Límites Máximos Permisibles de Emisión de Ruidos de las Fuentes Fijas y su Método de Medición,” Publicada el 13 de Enero SEMARNAT, Secretaria del Medio Ambiente y Recursos Naturales, México, 1995, 15 p.

[32] DOF, Diario Oficial de la Federación, "Norma Oficial Mexicana, NOM-114-SEMARNAT-1998, Que Establece las Especificaciones de Protección Ambiental para la Planeación, Diseño, Construcción, Operación y Mantenimiento de Líneas de Transmisión y de Subtransmisión Eléctrica que se Pretendan Ubicar en áreas Urbanas, Suburbanas, Rurales Agropecuarias, Industriales, de Equipamiento Urbano o de Servicios y Turísticas,” Publicada el 23 de noviembre SEMARNAT, Secretaria del Medio Ambiente y Recursos Naturales, México, 1998, 9 p.

[33] DOF, Diario Oficial de la Federación, “Norma Oficial Mexicana, NOM-052-SEMARNAT-2005. Que Establece las Características el Procedimiento de Identificación, Clasificación y Los Listados de Los Residuos Peligrosos,” Publicada el 23 de Junio, Secretaria del Medio Ambiente y Recursos Naturales, México, 2006, 32 p.

[34] DOF, Diario Oficial de la Federación, "Norma Oficial Mexicana, NOM-004-CNA-1996, Requisitos Para la Protección de Acuíferos Durante el Mantenimiento y Rehabilitación de Pozos de Extracción de Agua y Para el Cierre de Pozos en General,” Publicada el 24 de Julio, Secretaria del Medio Ambiente, Recursos Naturales y Pesca-Comisión Nacional del Agua, México, 1997, 7 p.

[35] DOF, Diario Oficial de la Federación, "Ley de Aguas Nacionales,” Publicada el 1 de diciembre, Última reforma DOF el 8 de junio, México, 2012, 106 p.

[36] E. Mendoza-Rangel and C. Hernández-Ayala, "La Protección Ambiental en el Campo Geotérmico de Los Azufres, Mich,” Geotermia, Revista Mexicana de Geoenergía, Vol. 17 No. 1, 2004, pp. 2-9.

[37] G. R. Maya and L. Gutiérrez-Negrín, "Recursos Geotérmicos para Generar Electricidad en México,” Revista Digital Universitaria, Vol. 8, No. 12, , 2007, 12 p. http://www.revista.unam.mx/Vol.8/num12/dic_art91.pdf

[38] S. Rodríguez, H. Geysel and D. Speirs, "Control System Concepts to Improve Geothermal Plant Availability," Geotermia, Revista Mexicana de Geoenergía, Vol. 25, No. 2, 2012, pp. 43-49. 